\title{
Efficiency of Egyptian mulberry water extracts in controlling nephropathy complications in diabetic rats
}

\section{Heba Barakat, Nora M. El-Sheihk and Huda E. Mogahed}

Biochemistry and Nutrition Department

Faculty of Women for Arts, Science and Education, Ain Shams University, Cairo, Egypt

\begin{abstract}
The aim of the present study was to determine the amount and antifree radical activity of Deoxynojirimycin (DNJ) in Egyptian white and black mulberry fruits and leaves water extracts. Moreover, the study aimed to evaluate the water extracts effect of Egyptian white and black mulberry fruits and leaves, on improving hyperglycemic condition and renal complications in diabetic rats.

Seventy-two adult male albino rats Sprague-Dawley strain were equally divided into six groups: group (1) healthy control and group (2) diabetic control were given tap water by gavage tube, groups (3-6) diabetic treated with different water extracts of mulberry white fruits (WMFWE), white leaves (WMLWE), black fruits (BMFWE) and black leaves (BMLWE) (containing $50 \mathrm{mg}$ DNJ/kg body weight) by gavages' tube daily for 28 days. At the end of the experiment, rats were sacrificed under ether anesthesia. Blood samples were collected to separate serum; also kidneys were removed for biochemical parameters estimation.

The High Performance Liquid Chromatography (HPLC) analysis of the mulberry extracts showed that water extracts contained higher amount of DNJ than methanol or ethanol extracts. Also mulberry leaves had higher amount of DNJ than fruits and the amount of DNJ in black mulberry was more than the white one.

The treatment with mulberry water extracts effectively decreased the blood glucose level, glycated hemoglobin percentage, renal aldose reductase activity and renal protein level as compared to untreated diabetic control rats; on the other hand there was an elevation of insulin level. Also mulberry extracts ameliorate the oxidative stress status with significant elevation in nonenzymatic antioxidant with significant improvement in kidney function parameters. Based on the presented data in this study, it can be concluded that mulberry extracts possess antidiabetic effect and improving properties of nephropathy complications.
\end{abstract}

Key words: Rats; diabetes; mulberry; Deoxynojirimycin; aldose reductase and oxidative stress

\section{Introduction}

Worldwide, the prevalence of diabetes was estimated at 171 million in 2000, increasing to 382 million in 2013; and is projected to reach 592 million by 2035 .

Corresponding author: Dr. Heba Adel Barakat.

E.mail: dr_hebabarakat@yahoo.com Tel: 01225990590 
This represents $8 \%-10 \%$ of the global population, resulting in at least 548 billion dollars in health expenditure on diabetes care (Centers for Disease Control and Prevention, 2014 ).

Diabetes classified mainly as type 1 (autoimmune $\beta$-cell destruction and absolute insulin deficiency) and type 2 (relative insulin deficiency and resistance). Diabetic Nephropathy (DN) or diabetic kidney disease is a syndrome characterized by the presence of pathological diabetic glomerular lesions, and loss of glomerular filtration rate (GFR) in diabetics (Lim, 2014).

The diabetes epidemic has resulted in DN becoming the most frequent cause of end-stage renal disease (ESRD) in most countries. In 2009-2011, diabetes was the primary cause of ESRD in about $40-60 \%$ of patients in many countries. The incidence of ESRD due to diabetes also rises in the older age group (Centers for Disease Control and Prevention, 2014 ).

In diabetics who develop DN, progression is variable. The main modifiable risk is glycemic control, oxidative stress and generation of reactive oxygen species (ROS) which damage DNA and protein, or function as signaling amplifiers to activate cellular stress pathways such as protein kinase C (PKC) and activation of mitogenactivated protein kinases (MAPK) (Ha and Lee, 2000 and Tapp et al., 2004). Activation of the polyol pathway, with aldose reductase converting excess glucose to sorbitol, and subsequent conversion to fructose by sorbitol dehydrogenase contributes to oxidative stress by increasing the NADH/NAD ${ }^{+}$ratio (Srivastava et al., 2005).

Plants are exemplary source of medicines and several drugs have been derived directly or indirectly from them. Mulberry is medicinally important plant which belongs to genera Morus. The Chinese Pharmacopoeia (1985) lists the leaves, root bark, branches, and fruits as ingredients in medicinal preparations, but other parts, including the sap and wood ash are also widely used. The Morus plant is also a rich source of natural isoprenoid substituted phenolic compounds including flavanoids. These compounds have been studied by many investigators with structural, biological and pharmacological interests (Kumar and Chauhan, 2008 and Sun et al., 2011).

Deoxynojirimycin (1,5-dideoxy-1,5-imino-D-glucitol; DNJ) is a polyhydroxy alkaloid typical of the six-membered ring piperidine group. It has been shown to be a potent $\alpha$-glucosidase inhibitor. Its presence has been described in leaves and roots of Morus sp. in which its content has been used as antihyperglycemic quality criterion (Kim et al., 2003 and Rodríguez-Sánchez et al., 2011).

The goal of the present investigation was to select the extract with the highest DNJ content from different mulberry extracts. Moreover to determine antifree radical activity of the selected extract and it's biological and biochemical impact on the alleviation of the diabetic status and its complications in diabetic rats. 


\section{Materials and methods}

\subsection{Materials}

\subsubsection{Plant}

White (Morus alba L.) and black (Morus nigra Linn.) mulberry fruits and leaves were obtained from the Ministry of Agriculture and Land Reclamation in MayJune 2013. The fruits and leaves were cleaned, air dried and ground into powder, then stored at $4{ }^{\circ} \mathrm{C}$ until further use.

\subsubsection{Chemicals}

- Streptozotocin (STZ), acetonitrile and DNJ were purchased from Sigma- Aldrich (USA).

- Other chemicals were all of analytical reagent grade purchased from Elgomhorya Company, Cairo, Egypt.

\subsubsection{Animals}

Seventy-two healthy adult male albino rats Sprague-Dawley strain with mean weight range 217-220g, were obtained from the Breeding Unit of the Egyptian Organization for Biological Products and Vaccines, Helwan, Egypt.

\subsubsection{Diet}

The experimental diet used in the present study was the balanced diet prepared according to American Institute of Nutrition AIN -93 and adjusted by Reeves et al. (1993) with some modifications (El-Sheikh and Khalil, 2011). The composition of the balanced diet (g/100g diet), Cornstarch 62.07, Casein 14.0, Sucrose 10.0, Corn oil 4.0, Fiber 5.0, Mineral mixture 3.5, Vitamin mixture 1.0, L-cystine 0.18 and Choline bitartrate 0.25 .

\subsection{Methods}

\subsubsection{Determination of DNJ in the different extracts by HPLC}

To determine the best solvent for DNJ extraction, one gram of mulberry fruits and leaves powder were soaked in $10 \mathrm{ml}$ of different solvents $(70 \%$ methanol, $70 \%$ ethanol and tap water) for $30 \mathrm{~min}$ at room temperature, then filtered and the filtrates were evaporated at $72-75^{\circ} \mathrm{C}$ to final volume from 2 to $4 \mathrm{ml}$ (Nuengchamnong et al., 2007).

HPLC device was used in the Central Lab., Faculty of Pharmacy, Cairo University for the quantitative determination of DNJ in different mulberry extracts using Agilent-C18 and a mixture of acetonitrile: aqueous $0.1 \%$ acetate $(51: 49 \mathrm{v} / \mathrm{v})$ as a mobile phase at a flow rate of $1.0 \mathrm{ml} / \mathrm{min}$; at $30^{\circ} \mathrm{C}$. A UV detector was used with 
excitation wavelength of $254 \mathrm{~nm}$ and emission wavelength of $322 \mathrm{~nm}$ (Hu et al., 2011).

\subsubsection{Preparation of the different water extracts}

After determination of tap water as the best extract, ten grams of four mulberry fruits and leaves powder were soaked in $100 \mathrm{ml}$ of water for $30 \mathrm{~min}$ at room temperature, and then filtered and the filtrates were evaporated at $72-75^{\circ} \mathrm{C}$ to final volume from 20 to $40 \mathrm{ml}$.

\subsubsection{Determination of antifree radical activity}

The hydroxyl radical scavenging assay of the water extract of white and black mulberry fruits and leaves was measured according to the method of Luo and Fang (2008).

\subsection{Experimental design}

Seventy two adult male rats Sprague-Dawely strain were acclimatized at the laboratory condition for 1 week prior to the start of the experiment. They were kept individually in stainless steel cages with $12 \mathrm{~h}$ light-dark cycle and temperature of $25 \pm$ $5{ }^{\circ} \mathrm{C}$. The food and water were introduced in special cups ad libitum. Diabetes was induced in sixty rats by STZ. STZ was dissolved in cold citrate buffer (0.1M, pH 4.5) and then injected subcutaneously in a dose of $40 \mathrm{mg} / \mathrm{kg}$ body weight after an overnight fasting. The other 12 rats (healthy rats) were injected subcutaneously with citrate buffer (Volpato et al., 2011). After injection with STZ, the rats were given a sucrose solution $5 \%$ for $24 \mathrm{~h}$ instead of the drinking water to overcome STZ-induced hypoglycemia (Ibrahim and Rizk, 2008).

The diabetic status was assessed by measuring $12 \mathrm{~h}$ fasted blood glucose concentration using the glucometer 3 days after STZ injection (concentration exceeded $200 \mathrm{mg} / \mathrm{dl}$ confirming the diabetic status). Then diabetic rats were divided into 5 groups: diabetic control, diabetic treated with different water extracts of mulberry white fruits (WMFWE), white leaves (WMLWE), black fruits (BMFWE) and black leaves (BMLWE), respectively using the gavages' tube. All the water extracts were freshly prepared and administered at a daily dose containing $50 \mathrm{mg}$ $\mathrm{DNJ} / \mathrm{kg}$ body weight intragastrically for 4 weeks (Li et al., 2011).

\subsubsection{Handling of blood and kidney samples}

At the end of the experiment all rats were fasted overnight and sacrificed under ether anesthesia. Blood samples were collected from the hepatic portal vein to separate serum for biochemical analyses. Kidneys samples were immediately removed and cleaned, rinsed with cold physiological saline solution $(0.9 \%)$ then blotted on filter paper and weighed to calculate the relative kidneys weight as described by Guo et al. (2002) then stored at $-20^{\circ} \mathrm{C}$ for further analyses. 
2.3.2. Biological assay: During the experimental period food intake was measured daily and animals were weighed weekly to monitor the body weight changes. The Feed Efficiency Ratio (FER) was calculated as described by the equation of Guo et al. (2002).

2.3.3. Biochemical assays: Blood glucose concentration, insulin level and glycohemoglobin (HA1C) percentage were determined by glucometer and Enzyme Immunoassay Test kit according to Wayne (1998) and Gonen and Rubenstein (1978), respectively. Renal aldose reductase (AR), total protein, nitric oxide (NO), malondialdehyde (MDA), advanced oxidation protein products (AOPPs) and reduced glutathione (GSH) were determined according to Suzen et al. (2007), Tietz (1994), Montogomery and Dymock (1961), Uchiyama and Mihara (1978), modification of Witko's method (Witko et al ., 1992) and Beutler et al. (1963), respectively. Serum creatinine, urea, uric acid and total protein were assayed as described by Jaffe (1986), Fawecett and Scott (1960), Gochman and Schmitz (1971), and Tietz (1994), respectively.

2.4 Statistical analysis: The data were statistically analyzed by SPSS version 17.0 statistical packages. Data were presented as mean \pm S.D. statistical differences between groups were performed using student t-test, differences considered significant when $\mathrm{P}<0.05$ (Levesque, 2007).

\section{Results and Discussion}

\subsection{DNJ content and the best extract}

DNJ contents in different extracts are shown in table (1). HPLC analysis of the different tested extracts showed that, the extraction of DNJ from mulberry leaves and fruits by water had the highest concentration, followed by methanol then ethanol. Moreover the results showed that, among the different water extracts, the concentrations of DNJ were arranged descendingly as follows; BMLWE, WMLWE, WMFWE and BMFWE.

Table (1): DNJ contents of different tested extracts

\begin{tabular}{|c|c|c|c|c|}
\hline $\begin{array}{c}\text { Sample } \\
\text { Solvent }\end{array}$ & $\begin{array}{c}\text { Black mulberry } \\
\text { leaves (mg \%) }\end{array}$ & $\begin{array}{c}\text { Black mulberry } \\
\text { fruits (mg \%) }\end{array}$ & $\begin{array}{c}\text { White mulberry } \\
\text { leaves (mg \%) }\end{array}$ & $\begin{array}{c}\text { White mulberry } \\
\text { fruits (mg \%) }\end{array}$ \\
\hline Water & 313.6 & 32.6 & 137.7 & 70.8 \\
\hline Methanol & 156.5 & 39.5 & 110.5 & 67 \\
\hline Ethanol & 79.9 & 51.5 & 31.3 & 40.7 \\
\hline
\end{tabular}

Our results were matched with the results of Rodríguez-Sánchez et al. (2013) who compared the different extracted DNJ from mulberry leaves at ambient 
temperature with different solvents (water, methanol and ethanol). They concluded that water had the efficiency to extract more DNJ than both methanol and ethanol.

\subsection{Antifree radical activity of standard DNJ and water extracts}

The antioxidant activity of the standard DNJ solution and the different mulberry water extracts which were measured by hydroxyl radicals $(\mathrm{OH})^{-}$scavenging assays are illustrated in figure (1). The results showed that scavenging effect of the hydroxyl radicals by DNJ in each of mulberry extract were increased by increasing its concentration in the extracts. The scavenging effects were from 11.6 to $41.4 \%$ (concentration range from 1.25 to $100 \mu \mathrm{g} / \mathrm{ml}$ ), respectively.

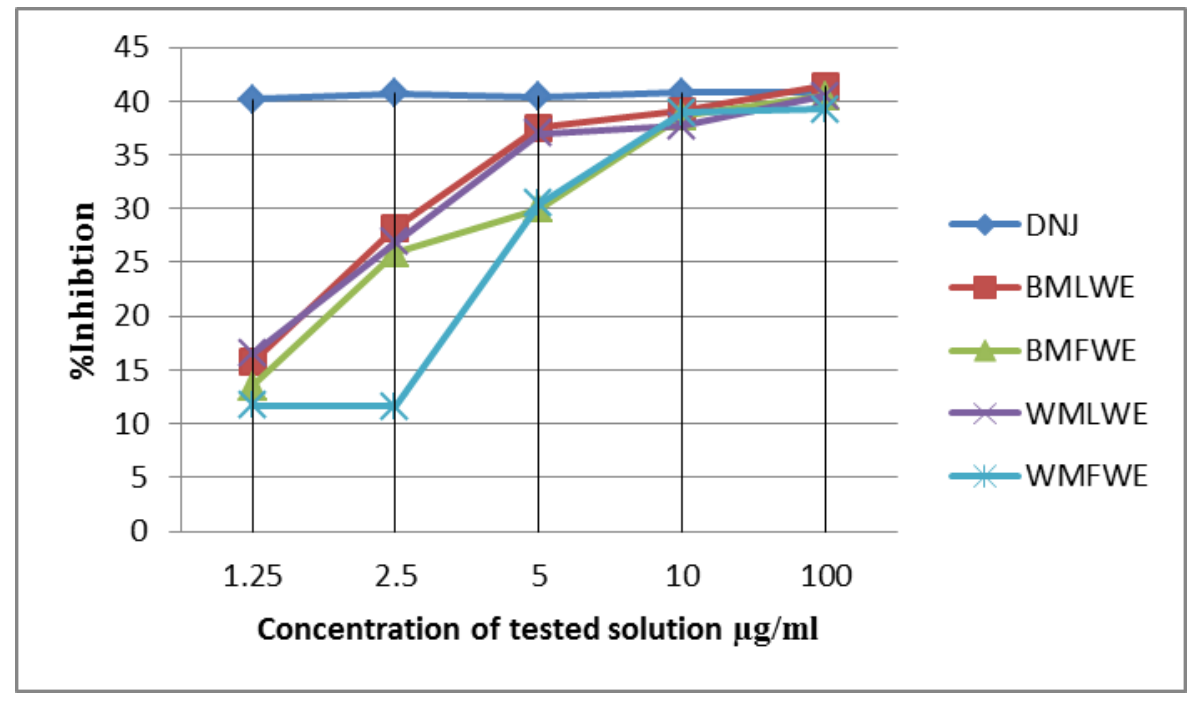

Figure (1): Scavenging effect of standard DNJ solution and different mulberry water extracts as \% of inhibition.

\subsection{Effect of oral doses of the different water extracts on the biological parameters}

During the experiment period, six rats were died from different groups.

The biological trail elucidated the potential effects of mulberry water extracts oral administration on some of the biological investigations in diabetic rats such as the food intake, body weight changes, feed efficiency ratio and relative kidneys weight were illustrated in table (2).

The subcutaneous injection of STZ (40 mg/kg body weight) resulted in a significant loss of body weight by $97.66 \pm 30.73 \mathrm{~g}$ and a statistically significant increment in food intake about $954.00 \pm 101.36 \mathrm{~g}$ ( $\mathrm{p}<0.05)$ as compared with the healthy control group which recorded an increase in body weight value $50.83 \pm$ $17.41 \mathrm{~g}$ and food intake $667.00 \pm 74.73 \mathrm{~g}$ at the end of the experiment. 
Table (2): Effect of the different mulberry water extracts on the biological parameters at the end of the experiment

\begin{tabular}{|c|c|c|c|c|}
\hline Group & $\begin{array}{c}\text { Food intake } \\
\text { (g) }\end{array}$ & $\begin{array}{c}\text { Change in } \\
\text { body weight (g) }\end{array}$ & $\begin{array}{c}\text { Feed } \\
\text { Efficiency } \\
\text { Ratio }\end{array}$ & $\begin{array}{c}\text { Relative } \\
\text { kidneys } \\
\text { weight }(\%)\end{array}$ \\
\hline Healthy & $667.00 \pm 74.73^{c}$ & $50.83 \pm 17.41^{\mathrm{a}}$ & $0.08 \pm 0.04^{\mathrm{a}}$ & $0.25 \pm 0.06^{\mathrm{c}}$ \\
\hline $\begin{array}{l}\text { Diabetic } \\
\% \text { of change }\end{array}$ & $\begin{array}{c}954.00 \pm 101.36^{\mathrm{a}} \\
43.03\end{array}$ & $\begin{array}{c}-97.66 \pm 30.73^{\mathrm{c}} \\
-292.13\end{array}$ & $\begin{array}{c}-0.1 \pm 0.04^{\mathrm{c}} \\
-225.00\end{array}$ & $\begin{array}{c}0.46 \pm 0.01^{\mathrm{a}} \\
84.00\end{array}$ \\
\hline $\begin{array}{l}\text { WMFWE } \\
\% \text { of change } \\
\% \text { of change }\end{array}$ & $\begin{array}{c}844.66 \pm 65.76^{b} \\
26.64 \\
-11.46\end{array}$ & $\begin{array}{c}-46.50 \pm 29.84^{b} \\
191.48 \\
52.39\end{array}$ & $\begin{array}{c}-0.05 \pm 0.03^{\mathrm{b}} \\
-162.50 \\
50.00\end{array}$ & $\begin{array}{c}0.40 \pm 0.06^{\mathrm{a}, \mathrm{b}} \\
60.00 \\
-13.04\end{array}$ \\
\hline $\begin{array}{l}\text { WMLWE } \\
\% \text { of change } \\
\% \text { of change }\end{array}$ & $\begin{array}{c}960.66 \pm 109.99^{\mathrm{a}} \\
44.03 \\
0.61\end{array}$ & $\begin{array}{c}-61.66 \pm 27.50^{b, c} \\
-221.31 \\
36.87\end{array}$ & $\begin{array}{c}-0.06 \pm 0.03^{b, c} \\
-175.00 \\
40.00\end{array}$ & $\begin{array}{c}0.44 \pm 0.17^{\mathrm{a}} \\
76.00 \\
4.35\end{array}$ \\
\hline $\begin{array}{l}\text { BMFWE } \\
\% \text { of change* } \\
\% \text { of change }\end{array}$ & $\begin{array}{c}817.75 \pm 107.54^{b} \\
22.60 \\
-14.28\end{array}$ & $\begin{array}{c}-41.83 \pm 14.95^{b} \\
-182.29 \\
57.17\end{array}$ & $\begin{array}{c}-0.05 \pm 0.02^{b} \\
-162.50 \\
50.00\end{array}$ & $\begin{array}{c}0.32 \pm 0.09^{b, c} \\
28.00 \\
-30.43\end{array}$ \\
\hline $\begin{array}{l}\text { BMLWE } \\
\% \text { of change* } \\
\% \text { of change* }\end{array}$ & $\begin{array}{c}800.33 \pm 50.33^{b} \\
19.99 \\
-16.11\end{array}$ & $\begin{array}{c}-65.66 \pm 50.52^{b, c} \\
-229.18 \\
32.77\end{array}$ & $\begin{array}{c}-0.08 \pm 0.06^{b, c} \\
-200.00 \\
20.00\end{array}$ & $\begin{array}{c}0.45 \pm 0.09^{\mathrm{a}} \\
80.00 \\
2.17\end{array}$ \\
\hline
\end{tabular}

Values are represented as mean \pm SD ( $n=10-12$ rats). Each value is considered statistically significant at $\mathrm{p} \leq 0.05$.

Groups sharing the same superscripts are not statistically different.

$*_{\%}$ of change from healthy rats

$* *_{\%}$ of change from diabetic rats.

However the administration of different mulberry water extracts for 28 days to STZ-injected rats decreased the loss in body weight to reach $46.50 \pm 29.84,61.66 \pm$ $27.50,41.83 \pm 14.95$ and $65.66 \pm 50.52 \mathrm{~g}$ for WMFWE, WMLWE, BMFWE and BMLWE, respectively. On the other hand all groups treated with mulberry extracts showed significant decrement $(\mathrm{p}<0.05)$ in the food intake values compared with diabetic group except WMLWE group.

Concerning the FER, there was a significant reduction $(p<0.05)$ in diabetic rats compared with healthy control group whereas treatment with WMFWE and BMFWE caused significant improvement $(p<0.05)$ in the FER values when compared with the diabetic control group. 
The relative kidneys weight was significantly increased in the diabetic control group with value equal $0.46 \pm 0.01$, while treatment with WMFWE, WMLWE and BMLWE recorded insignificant improvement ( $p>0.05$ ) $0.40 \pm 0.06,0.44 \pm 0.17$ and $0.45 \pm 0.09$, respectively as compared with the diabetic control group. However, the diabetic group treated with BMFWE was the most effective one that recorded $0.32 \pm$ 0.09 with no significant difference with the healthy control group which recorded 0.25 \pm 0.06 .

The classic symptoms of untreated diabetes of weight loss, polyuria, polydipsia and polyphagia were clarified in this experiment due to disorders in carbohydrate, fat and protein metabolism. Hence there was an unavailability of carbohydrate as an energy source in the case of high blood sugar and insulin deficiency, body fat and protein catabolism was increased. This fact could explain the increased values of food intake and weight loss in untreated diabetic rats. While, treatment with different mulberry extracts, the hyperglycemia status was controlled and insulin production was increased leading to an improvement in body weight and all the other biological parameters.

The food consumption and change in body weight in different groups of rats were investigated by Andallu and Varadacharyulu (2003) and were consistent with our results. Their results showed a significant increase by $12 \%$ in food consumption and a decrease in body weight in diabetic control group. However, mulberry treatment decreased food consumption insignificantly and increased the body weight in diabetic rats. Also the results reported by Li et al. (2011) showed that diabetic mice treated with DNJ extracted from mulberry have an increasing tendency of body weight gain.

The elevation in the body-kidney weight ratio of diabetic rats as compared with control rats was explained by Gupta et al. (2011) as a result of fatty infiltration, enlargement of tubular cells lining, large hemorrhagic area and lymphocyte infiltration in hyperglycemic rats.

\subsection{Effect of oral doses of the different water extracts on the progression of diabetes and its renal complications}

The results of blood glucose and serum insulin levels were shown in table (3) clarified that STZ-diabetic rats elucidated a significant rise in blood glucose level to $269.12 \pm 11.55 \mathrm{mg} / \mathrm{dl}$ and a low insulin level of $2.54 \pm 0.14 \mu \mathrm{IU} / \mathrm{ml}$ as compared to the healthy control group in which glucose level was $78.1 \pm 3.62 \mathrm{mg} / \mathrm{dl}$ while insulin level was $4.18 \pm 0.09 \mu \mathrm{IU} / \mathrm{ml}$. On the other hand, the STZ diabetic rats treated with the four different tested extracts showed a significant decrease in blood glucose levels and increase in insulin level, especially the rats that were administered with the BMLWE, which exhibited the highest improvement for blood glucose and insulin level.

STZ has a structure similar to glucose (Glu) and N-acetyl glucosamine (GlcNAc). STZ is taken up by pancreatic $\beta$-cells via the GLUT 2 transporter where it 
causes $\beta$-cell death by DNA fragmentation due to the nitrosourea moiety. Three major pathways are associated with the cell death: (i) methylation of DNA by the formation of carbonium ion $\left(\mathrm{CH}^{3+}\right)$ resulting in the activation of the nuclear enzyme poly ADP-ribose synthetase as part of the cell repair mechanism and therefore $\mathrm{NAD}^{+}$depletion; (ii) free radical generation as hydrogen peroxide and (iii) nitric oxide production (Ventura-Sobrevilla et al., 2011). Similarly, DNJ has comparable size and, to some extent, close structure to D-glucose so, it has been postulated to inhibit D-glucose uptake at the intestinal brush border membrane. DNJ affects the final step of carbohydrate digestion in the intestinal lumen and retards the absorption of dietary carbohydrates to suppress postprandial hyperglycemia (Kwon et al., 2011).

Andallu and Varadacharyulu (2001) concluded that the treatment of diabetic rats with mulberry extract decreased the blood glucose level in comparison with untreated diabetic rats. Also Li et al. (2011) reported that rats treated with DNJ extracted from mulberry showed decreased blood glucose level as compared with diabetic group, and improvement in insulin level as compared with untreated diabetic group.

The scavenging activity of the tested extracts $(5 \mu \mathrm{g} / \mathrm{ml})$ for $\mathrm{H}_{2} \mathrm{O}_{2}$ as well as NO levels revealed that BMLWE displayed the most scavenging activity and had the most improvement effect for insulin and glucose levels, followed by WMLWE.

The injection with STZ caused a highly significant increment in the HA1C \% and renal AR activity with values $28.26 \pm 0.43 \%$ and $6.59 \pm 0.16 \mu \mathrm{mol} / \mathrm{g}$, respectively. While the treatment of diabetic rats with the different mulberry extracts caused a noticeable decrease $(\mathrm{p}<0.05)$ in HA1C \% and AR activity as compared with the results of untreated diabetic control group which had the highest values among all the groups as recorded $28.26 \pm 0.43 \%$ and $6.59 \pm 0.16 \mu \mathrm{mol} / \mathrm{g}$ for HA1C \% and renal AR activity, respectively.

A significant increase in the activity of renal aldose reductase in the diabetic untreated rats may be attributed to hyperglycemic status and the high levels of the free radicals and diminished antioxidant system. On the other hand, treatment with the four different tested extracts improved blood glucose level and enhanced antioxidant system and subsequently lowered the aldose reductase activity. The inhibition of aldose reductase is a vital strategy towards control of further cascade of reactions culminating in the generation of sorbitol, oxidative stress and damage to tissues. 
Table (3): Effect of the different mulberry water extracts on the progression of diabetes and its renal complications

\begin{tabular}{|c|c|c|c|c|c|}
\hline Group & $\begin{array}{l}\text { Final glucose } \\
(\mathrm{mg} / \mathrm{dl})\end{array}$ & $\begin{array}{l}\text { Insulin } \\
(\mu \mathrm{IU} / \mathrm{ml})\end{array}$ & $\begin{array}{c}\text { Glycated } \\
\text { hemoglobin } \\
(\%)\end{array}$ & $\begin{array}{c}\text { Renal aldose } \\
\text { reductase } \\
\text { ( } \mu \mathrm{mol} / \mathrm{g} \\
\text { tissue) }\end{array}$ & $\begin{array}{c}\text { Renal } \\
\text { protein } \\
\text { (g/100g } \\
\text { tissue) } \\
\end{array}$ \\
\hline Healthy & $78.10 \pm 3.62^{\mathrm{e}}$ & $4.18 \pm 0.09^{\mathrm{a}}$ & $7.63 \pm 0.19^{\mathrm{e}}$ & $2.70 \pm 0.08^{f}$ & $11.18 \pm 0.22^{\mathrm{a}}$ \\
\hline $\begin{array}{l}\text { Diabetic } \\
\% \text { of change }\end{array}$ & $\begin{array}{c}269.12 \pm 11.55^{\mathrm{a}} \\
244.58\end{array}$ & $\begin{array}{l}2.54 \pm 0.14^{\mathrm{e}} \\
-39.23\end{array}$ & $\begin{array}{c}28.26 \pm 0.43^{\mathrm{a}} \\
270.44\end{array}$ & $\begin{array}{c}6.59 \pm 0.16^{\mathrm{a}} \\
144.07\end{array}$ & $\begin{array}{c}4.29 \pm 0.16^{\mathrm{e}} \\
-61.65\end{array}$ \\
\hline WMFWE & $149.32 \pm 3.27^{b}$ & $3.27 \pm 0.07^{\mathrm{c}}$ & $9.76 \pm 0.12^{c}$ & $4.20 \pm 0.14^{\mathrm{c}}$ & $6.44 \pm 0.13^{\mathrm{d}}$ \\
\hline $\begin{array}{l}\% \text { of change } \\
\% \text { of change }\end{array}$ & $\begin{array}{l}91.19 \\
-44.52\end{array}$ & $\begin{array}{l}-21.77 \\
28.54\end{array}$ & $\begin{array}{c}28.00 \\
-65.46\end{array}$ & $\begin{array}{c}55.55 \\
-36.28\end{array}$ & $\begin{array}{l}-42.39 \\
50.11\end{array}$ \\
\hline WMLWE & $135.86 \pm 3.03^{c}$ & $3.30 \pm 0.08^{\mathrm{c}}$ & $9.47 \pm 0.16^{\mathrm{d}}$ & $3.61 \pm 0.11^{\mathrm{d}}$ & $7.61 \pm 0.13^{b}$ \\
\hline$\%$ of change & 73.96 & -21.10 & 24.12 & 33.70 & -31.93 \\
\hline$\%$ of changet & -49.52 & 29.80 & -66.48 & -45.22 & 77.38 \\
\hline BMFWE & $118.62 \pm 4.49^{\mathrm{d}}$ & $3.17 \pm 0.09^{\mathrm{d}}$ & $10.01 \pm 0.22^{b}$ & $4.64 \pm 0.14^{b}$ & $6.38 \pm 0.20^{d}$ \\
\hline$\%$ of change & 51.88 & -24.10 & 31.20 & 71.85 & -42.93 \\
\hline$\%$ of change & -55.92 & 24.96 & -64.57 & -29.50 & 48.72 \\
\hline BMLWE & $117.94 \pm 3.15^{\mathrm{d}}$ & $3.47 \pm 0.10^{b}$ & $9.35 \pm 0.17^{\mathrm{d}}$ & $3.38 \pm 0.17^{\mathrm{e}}$ & $7.20 \pm 0.14^{\mathrm{c}}$ \\
\hline$\%$ of change & 51.01 & -16.98 & 22.54 & 25.20 & -35.59 \\
\hline$\%$ of changet & -56.18 & 36.61 & -66.89 & -48.78 & 67.83 \\
\hline
\end{tabular}

Legend as in table (2)

This conclusion was emphasized by the previous study of Maritim et al. (2003) who reported that in the STZ- induced diabetic rats, sorbitol levels and glycosylated concentration in the lens proteins were lowered and hence cataract formation was inhibited as a result of administration with aldose reductase inhibitors (tolrestat or polnatrestat).

Total protein in kidney tissue was affected by STZ injection. The untreated diabetic rats had the most significant low values of renal total protein comparing with healthy control group. However diabetic rats treated with the four mulberry extracts (WMFWE, WMLWE, BMFWE and BMLWE) showed significant improvement in renal total protein concentration. These results were correlated to that previously illustrated for insulin. In diabetic group, there was a decrease in the insulin production due to the destruction of the pancreatic $\beta$-cells responsible for its production, which in turn led to protein destruction for glucose replenishment. However the other groups treated with the different mulberry water extracts had an improvement in insulin 
production, therefore the protein content in the renal tissues was protected in a great extent from catabolism.

These results are correlated with that of the glucose and insulin levels as previously illustrated. It may be explained according to the high affinity of glucose in case of hyperglycemia to bind with $\mathrm{Hb}$ forming glycosylated $\mathrm{Hb}$. This explanation is confirmed by that of Palsamy and Subramanian (2009) who reported that the persistent supra-physiological level of glucose reacts with $\mathrm{Hb}$ to form glycosylated hemoglobin, which is a standard biochemical marker for the diagnosis of ambient glycemia.

The reduction in protein was explained by either increased protein catabolism; decreased amino acid uptake; greatly decreased concentration of variety of essential amino acids, increased conversion rate of glycogenic amino acids to carbon dioxide and water, and/or reduction in protein synthesis secondary to a decreased amount and availability of mRNA (Ahmed, 2005). While treatment with mulberry water extracts effectively controlled hyperglycemic condition, improved insulin production and decreased AR activity. All these factors possibly led to a reduction in tissue protein catabolism and controlling the conversion rate of glycogenic amino acids to carbon dioxide and water also insulin had a sparing effect on proteins. Moreover protein synthesis was decreased in all tissues due to decreased production of ATP in absolute or relative deficiency of insulin. Insulin generally has an anabolic effect on protein metabolism in that it stimulates protein synthesis and retards protein degradation (Murray et al., 2000).

Ventura-Sobrevilla et al. (2011) found that single intraperitoneal injection of STZ $40 \mathrm{mg} / \mathrm{kg}$ body weight caused an increment in glycated hemoblobin \% in diabetic group. Moreover Dongare et al. (2012) showed the same results by a single intraperitoneal injection of STZ with an increase in lens AR activity in rats.

\subsection{Effect of oral doses of mulberry water extracts on some oxidative stress and antioxidant biomarkers}

The results in table (4) showed that the levels of renal nitric oxide, MDA and AOPPs significantly increased in diabetic rats by about 5.5, 1.4 and 3.2 times, respectively as compared to healthy control rats. While diabetic rats showed decrement in renal GSH content by 1.4 times as compared to control rats, on the other hand treatment with mulberry extracts (WMFWE, WMLWE, BMFWE and BMLWE) caused a significant reduction in renal NO, MDA and AOPPs values and a significant increase in renal GSH content.

A popular measurement used to quantify the effect of hydroxyl radical damage in cells is the MDA, which is formed when polyunsaturated fatty acyl chains are attacked by hydroxyl radicals. As expected, diabetic group had the highest MDA level while groups treated with the four different mulberry water extracts showed 
improvement in MDA level compared with diabetic group which may be due to the antifree radical activity of DNJ in the tested extracts.

Reduced glutathione is a major intracellular redox buffer functions as a direct free-radical scavenger. Reduction of glucose to sorbitol uses NADPH and oxidation of sorbitol increases NADH with a resultant rapid change in the cytoplasmic redox status. Decreased (altered cytosolic ratio of NADPH: $\mathrm{NADP}^{+}$) may compromise reduction of glutathione in oxidatively stressed cells (Dunlop, 2000 and Maritim et al., 2003)

Kayali et al. (2006) reported that $(\mathrm{ONOO})^{-}$is a cytotoxic species generated when superoxide radicals $\left(\mathrm{O}^{-2}\right)$ combine with nitric oxide (NO), and its formation has been implicated in both the origin and progression of protein oxidation. Nitration of the ortho position of tyrosine is a major product of $\mathrm{ONOO}^{-}$attack on proteins, leading to nitrotyrosine (NT), and it has been considered a specific marker for the detection of $\mathrm{ONOO}^{-}$in vivo. AOPPs are defined as dityrosine-containing cross- linked protein products.

The increased renal NO level was explained by Yildirim (2010) as a result of some disturbances in amino acid metabolism in diabetes that may be contributed to the increased intra renal NO production. In addition, the increased glucose concentration in diabetes induces elevation in intracellular levels of diacylglycerol that activates protein kinase $\mathrm{C}$, and consequently the nitric oxide synthase is activated.

Table (4): Effect of the different mulberry water extracts on some oxidative stress and antioxidant biomarker

\begin{tabular}{|c|c|c|c|c|}
\hline Group & $\begin{array}{c}\text { Nitric oxide } \\
(\mu \mathrm{mol} / \mathrm{g} \text { tissue })\end{array}$ & $\begin{array}{c}\text { Malondialdehyde } \\
\text { (mmol/g tissue) }\end{array}$ & $\begin{array}{c}\text { Advanced } \\
\text { oxidation } \\
\text { protein products } \\
\text { (nmol/g tissue) } \\
\end{array}$ & $\begin{array}{c}\text { Reduced } \\
\text { glutathion } \\
\text { (mg/g tissue) }\end{array}$ \\
\hline Healthy & $3.33 \pm 0.10^{f}$ & $0.67 \pm 0.01^{\mathrm{c}}$ & $3.01 \pm 0.09^{\mathrm{e}}$ & $92.20 \pm 0.71^{\mathrm{a}}$ \\
\hline $\begin{array}{l}\text { Diabetic } \\
\% \text { of change }\end{array}$ & $\begin{array}{c}18.66 \pm 0.79^{\mathrm{a}} \\
459.57\end{array}$ & $\begin{array}{c}0.94 \pm 0.02^{\mathrm{a}} \\
40.29\end{array}$ & $\begin{array}{c}9.74 \pm 0.06^{\mathrm{a}} \\
223.58\end{array}$ & $\begin{array}{c}67.31 \pm 0.76^{\mathrm{e}} \\
-26.99\end{array}$ \\
\hline $\begin{array}{l}\text { WMFWE } \\
\% \text { of change* } \\
\% \text { of change* }\end{array}$ & $\begin{array}{l}6.62 \pm 0.22^{\mathrm{c}} \\
98.79 \\
-64.52\end{array}$ & $\begin{array}{c}0.70 \pm 0.01^{b} \\
4.47 \\
-25.50\end{array}$ & $\begin{array}{c}4.29 \pm 0.10^{b} \\
42.52 \\
-55.95\end{array}$ & $\begin{array}{c}78.08 \pm 0.96^{b} \\
-15.31 \\
15.99\end{array}$ \\
\hline $\begin{array}{l}\text { WMLWE } \\
\% \text { of change* } \\
\% \text { of change* }\end{array}$ & $\begin{array}{l}6.21 \pm 0.12^{\mathrm{d}} \\
86.48 \\
-66.72 \\
\end{array}$ & $\begin{array}{c}0.70 \pm 0.01^{b} \\
4.47 \\
-25.50\end{array}$ & $\begin{array}{l}3.17 \pm 0.12^{\mathrm{d}} \\
5.13 \\
-67.50\end{array}$ & $\begin{array}{c}78.48 \pm 0.96^{b} \\
-14.88 \\
16.59\end{array}$ \\
\hline $\begin{array}{l}\text { BMFWE } \\
\% \text { of change* } \\
\% \text { of change* }\end{array}$ & $\begin{array}{c}9.511 \pm 0.15^{b} \\
185.58 \\
-49.03\end{array}$ & $\begin{array}{c}0.68 \pm 0.02^{\mathrm{c}} \\
1.49 \\
-27.65\end{array}$ & $\begin{array}{c}4.31 \pm 0.10^{b} \\
43.20 \\
-55.75\end{array}$ & $\begin{array}{c}74.82 \pm 1.05^{\mathrm{c}} \\
-18.85 \\
11.16\end{array}$ \\
\hline $\begin{array}{l}\text { BMLWE } \\
\% \text { of change* } \\
\% \text { of change* }\end{array}$ & $\begin{array}{c}5.69 \pm 0.14^{\mathrm{e}} \\
70.87 \\
-69.51\end{array}$ & $\begin{array}{c}0.68 \pm 0.01^{\mathrm{c}} \\
1.49 \\
-27.65\end{array}$ & $\begin{array}{c}3.54 \pm 0.07^{\mathrm{c}} \\
17.61 \\
-63.66\end{array}$ & $\begin{array}{c}71.79 \pm 0.86^{\mathrm{d}} \\
-22.14 \\
6.66\end{array}$ \\
\hline
\end{tabular}

Legend as in table (2) 
Our experimental findings supported the role for increased AR activity in such manifestations of oxidative stress as (a) superoxide generation, (b) lipid peroxidation, (c) depletion of the major biological antioxidant, reduced glutathione (GSH), (d) depletion of other important antioxidants, ascorbate and taurine, (e) down- induced injury (nitrosative stress) (Obrosova, 2005).

\subsection{Effect of oral doses of the different mulberry water extracts on renal function biomarkers}

From the data in table (5) it is clear that serum creatinine, urea and uric acid levels are significantly increased in diabetic rats by $2.5,1.5$ and 2.1 fold, respectively when compared with healthy control rats. While, diabetic rats treated with the tested extracts showed significant decrease in serum creatinine, urea and uric acid levels as compared with diabetic rats. The black and white leaves extracts were more effective in reducing serum creatinine, urea and uric acid levels than black and white fruits extracts.

Table (5): Effect of the different mulberry water extracts on renal function biomarkers

\begin{tabular}{|c|c|c|c|c|}
\hline Group & $\begin{array}{c}\text { Creatinine } \\
\text { (mg/dl) }\end{array}$ & $\begin{array}{l}\text { Urea } \\
\text { (mg/dl) }\end{array}$ & $\begin{array}{c}\text { Uric acid } \\
\text { (mg/dl) }\end{array}$ & $\begin{array}{l}\text { Total protein } \\
\text { (g/dl) }\end{array}$ \\
\hline Healthy & $0.97 \pm 0.01^{\mathrm{e}}$ & $27.70 \pm 0.69^{\mathrm{e}}$ & $2.29 \pm 0.19^{\mathrm{e}}$ & $7.42 \pm 0.09^{\mathrm{a}}$ \\
\hline $\begin{array}{l}\text { Diabetic } \\
\% \text { of change* }\end{array}$ & $\begin{array}{c}3.38 \pm 0.16^{\mathrm{a}} \\
248.45\end{array}$ & $\begin{array}{c}70.70 \pm 1.12^{\mathrm{a}} \\
155.22\end{array}$ & $\begin{array}{c}7.18 \pm 0.14^{\mathrm{a}} \\
213.50\end{array}$ & $\begin{array}{c}5.24 \pm 0.19^{\mathrm{e}} \\
-29.38\end{array}$ \\
\hline $\begin{array}{l}\text { WMFWE } \\
\% \text { of change } \\
\% \text { of change }\end{array}$ & $\begin{array}{l}2.67 \pm 0.10^{b} \\
175.26 \\
-21.00\end{array}$ & $\begin{array}{c}43.44 \pm 0.45^{b} \\
56.83 \\
-38.56\end{array}$ & $\begin{array}{c}4.42 \pm 0.14^{\mathrm{b}, \mathrm{c}} \\
93.01 \\
-38.44\end{array}$ & $\begin{array}{c}6.53 \pm 0.13^{\mathrm{b}, \mathrm{c}} \\
-11.99 \\
24.61\end{array}$ \\
\hline $\begin{array}{l}\text { WMLWE } \\
\% \text { of change* } \\
\% \text { of change }\end{array}$ & $\begin{array}{c}1.27 \pm 0.12^{\mathrm{d}} \\
30.29 \\
-62.43\end{array}$ & $\begin{array}{c}41.35 \pm 1.06^{\mathrm{c}} \\
49.28 \\
-41.52\end{array}$ & $\begin{array}{c}4.37 \pm 0.11^{\mathrm{c}} \\
90.18 \\
-39.13\end{array}$ & $\begin{array}{c}6.64 \pm 0.11^{b} \\
-10.51 \\
26.72\end{array}$ \\
\hline $\begin{array}{l}\text { BMFWE } \\
\% \text { of change* } \\
\% \text { of change } \\
\text { \% }\end{array}$ & $\begin{array}{c}1.64 \pm 0.13^{\mathrm{c}} \\
69.35 \\
-51.47\end{array}$ & $\begin{array}{c}43.84 \pm 0.64^{\mathrm{b}} \\
58.27 \\
-37.99\end{array}$ & $\begin{array}{l}4.53 \pm 0.11^{b} \\
97.80 \\
-36.90\end{array}$ & $\begin{array}{c}5.94 \pm 0.12^{\mathrm{d}} \\
-19.95 \\
13.36\end{array}$ \\
\hline $\begin{array}{l}\text { BMLWE } \\
\% \text { of change }\end{array}$ & $\begin{array}{c}1.26 \pm 0.07^{\mathrm{d}} \\
29.89\end{array}$ & $\begin{array}{c}39.18 \pm 0.82^{\mathrm{d}} \\
41.43\end{array}$ & $\begin{array}{c}3.76 \pm 0.15^{\mathrm{d}} \\
64.19\end{array}$ & $\begin{array}{c}6.49 \pm 0.10^{c} \\
-12.53\end{array}$ \\
\hline
\end{tabular}




\begin{tabular}{|l|l|l|l|l|}
\hline \% of change** & -62.72 & -44.59 & -47.63 & 23.85 \\
\hline
\end{tabular}

Legend as in table (2)

The results showed that STZ injected rats had significant lower serum total protein level by about 1.4 times than healthy control rats, while treatment with WMFWE, WMLWE, BMFWE and BMLWE improved serum total protein level.

An increase in creatinine, urea, uric acid and the decreased serum protein levels were detected either when the kidney is damaged or not functioning properly. Increment of blood creatinine, urea and uric acid and decreased serum protein levels with the high of blood sugar level clearly indicates that hyperglycemia caused kidney damage. Moreover diabetic nephropathy is characterized by progressive renal insufficiency. Hyperglycemia is thought to be mediating these injuries through induction of metabolic and biochemical changes due to increasing reactive oxygen species (ROS), NO production, oxidation and glycation of proteins and lipids and the impairment in body antioxidant defense system. Such explanation could be clearly supported by the data presented in this study.

AOPPs, ROS and free radicals produce protein carbonyl products (PCO) and are considered as markers of oxygen-mediated protein damage, also indicating changes in glomerular filtration barrier that result in the increased permeability of the cell membrane and loss of protein in urine (Madianov et al., 2000). In our study, mulberry extracts caused an increase in the serum protein levels and showed improvement in renal functions.

Decreased protein content of serum in diabetic patients were reported by Mahboob et al. (2005) who observed elevated lipid peroxidation process and decreased antioxidant defense system. Also Ganesan et al. (2011) reported that decreased protein content of serum in diabetics may be due to the inhibited oxidative phosphorylation processes which lead to both a decrease in protein synthesis and an increase in the catabolic process with reduction of protein absorption. Also Yassin and Mwafy (2007) reported that the degradation of protein and nucleic acid resulted in the formation of non-protein nitrogenous compounds such as urea, uric acid and creatinine which were elevated in diabetic rats due to catabolism of the protein and nucleic acids.

\section{Conclusion}

This study showed that Mulberry extracts possess antidiabetic, antioxidant and improving properties of nephropathy complications. Kidney functions and oxidantantioxidant status are highly altered in diabetes mellitus. This effect is directly by scavenging of free radicals and inhibition of renal aldose reductase activity, these properties of mulberry extracts may be due to its content of DNJ.

\section{References}


Ahmed R.G., The physiological and biochemical effects of diabetes on the balance between oxidative stress and antioxidant defense system, Med. J. Islamic World Acad. Sci. 15, 31-42 (2005).

Andallu B. and Vardacharyulu N.C.H., Effect of mulberry leaves on diabetes, Int. J. Diab. Dev. Countries. 21, 147-151 (2001).

Andallu B. and Varadacharyulu N.C.H., Antioxidant role of mulberry (Morus indica L. cv. Anantha) leaves in streptozotocin-diabetic rats, Clinica. Chimica. Acta. 338, 3 - 10 (2003).

Beutler E., Duroun O. and Kelly BM., Improved method for the determination of blood glutathione, J. Lab. Clin. Med. 61, 882-888 (1963).

Centers for Disease Control and Prevention, National diabetes fact sheet: national estimates and general information on diabetes and prediabetes in the United States (2014). Atlanta, GA: US Department of Health and Human Services.

Dongare V., kulkarni C., kondawar M., Magdum C., Haldavnekar V. and Arvindekar A., Inhibition of aldose reductase and anti-catarct action of transanethole isolated from foeniculum vulgare mill. fruits, Food Chem. 132, 385-390 (2012).

Dunlop M., Aldose reductase and the role of the polyol pathway in diabetic nephropathy, Kidney Int. 58 (77), S3-S12 (2000).

El-Sheikh N.M. and Khalil F.A., L- Arginine and L-glutamine as immunonutrients and modulating agents for oxidative stress and toxicity induced by sodium nitrite in rats, Food Chem. Toxicol. 49, 758-762 (2011).

Fawecett J.K. and Scott J.E., A rapid and precise method for the determination of urea, J. Clin. Path. 3, 156-159(1960). 
Ganesan K., Wilson J.S. and Palanisamy M., Effect of sinapic acid on biochemical markers and histopathological studies in normal and streptozotocin-induced diabetes in wistar rats, Int. J. Pharm. Sci. 3, 115-120 (2011).

Gochman N. and Schmitz J.M., Automated determination of uric acid, with use of a uricase-peroxidase system, Clin. Chem. 17, 1154 -1159 (1971).

Gonen B. and Rubenstein A.H., Determination of glycohemoglobin, Diabetologia. 15, 1-5 (1978).

Guo C.H., Huang C.J., Chiou X.I. and Hsu G.S.W., Alteration of trace element distribution and testis ACE activity in mice with high peritoneal aluminum, Biol. Trace Elem. Res. 85,145-157(2002).

Gupta R., Katariya P., Mathur M., Bajaj V.K., Yadav S., Kamal R. and Gupta R.S., Antidiabetic and renoprotective activity of momordica dioica in diabetic rats, Diabetologia Croatica. 40(3), 81-88 (2011).

Ha H. and Lee H.B., Reactive oxygen species as glucose signaling molecules in mesangial cells cultured under high glucose, Kidney Int Suppl. 77, S19-S25 (2000).

Hu K., Li Y., Du Y., Su B. and Lu D., Analysis of 1-deoxynojirimycin component correlation between medicinal parasitic loranthus from loranthaceae and their mulberry host trees, J. Med. Plant. Res. 5(17), 4326-4331 (2011).

Ibrahim S. S. and Rizk S. M., Nicotinamide: A cytoprotectant against streptozotocin induced diabetic damage in wistar rat brains, Afr. J. Biochem. Res. 2 (8), 174-180 (2008).

Jaffe M., Concerning the precipitate produced in normal urine by picric acid and a new reaction of creatinine, $Z$ Physiol. Chem. 10, 391-400 (1986). 
Kayali R., Cakatay U., Akcay T. and Altug T., Effect of alpha-lipoic acid supplementation on markers of protein oxidation in post-mitotic tissues of ageing rat, Cell Biochem. Funct. 24, 79-85 (2006).

Kim J.W., Kim S.U., Lee H.S., Kim I., Ahn M.Y. and Ryu K.S., Determination of 1-deoxynojirimycin in Morus alba L. leaves by derivatization with 9-fluorenylmethyl chloroformate followed by reversed-phase high-performance liquid chromatography, J. Chromatogr. A. 1002(1-2), 93-99 (2003).

Kumar V. R. and Chauhan S., Mulberry Life enhancer, J. Med. Plants Res. 2(10), 271-278 (2008).

Kwon H.J., Chung J.Y., Kim J.Y. and Kwon O., Comparison of 1deoxynojirimycin and aqueous mulberry leaf extract with emphasis on postprandial hypoglycemic effects, In Vivo and in Vitro studies. J. Agric. Food Chem. 59, 30143019 (2011).

Levesque R., SPSS programming and data management: A guide for SPSS and SAS users, $4^{\text {th }}$ ed. SPSS Inc, Chicago, IL (2007).

Li G.Y., Ji F.D., Zhong S., Lv Q.Z., Lin B.T., Chen S. and Hu Y.G., Hybrid of 1deoxynojirimycin and polysaccharide from mulberry leaves treat diabetes mellitus by activating PDX-1/insulin-1 signaling pathway and regulating the expression of glucokinase, phosphoenolpyruvate carboxykinase and glucose-6-phosphatase in alloxan-induced diabetic mice, J. Ethnopharmacol. 134, 961-970 (2011).

Lim A.K.H., Diabetic nephropathy - complications and treatment, Int. J. Nephrol. Renovasc. Dis. 7, 361-381 (2014).

Luo D.H., and Fang B.S., Structural identification of ginseng polysaccharides and testing of their antioxidant activities, Carbohydr Polym. 72, 376-81 (2008). 
Madianov I.V., Balabolkin M.I. and Markov D.S., Main causes of hyperuricemia in diabetes mellitus, Ter. Arkh. 72, 55-58 (2000).

Mahboob M., Rahman M.F. and Grover P., Serum lipid peroxidation and antioxidant enzyme levels in male and female diabetic patients, Singapore Med. J. 46, 322-324 (2005).

Maritim A.C., Sanders R. A. and Watkins J. B., Diabetes, oxidative stress, and antioxidants: A review, J. Biochem. Mol. Toxicol. 17, 24-38 (2003).

Montogomery H.A.C. and Dymock J.F., The determination of nitrate in water, Analyst. 86, 414-416 (1961).

Murray R.K., Granner D.K., Mayes P.A. and Rodwell V.W., Harper's biochemistry, $25^{\text {th }}$ ed. Appleton and Lange, Stanford CT, United States of America (2000).

Nuengchamnong N., Ingkaninan K., Kaewruang W., Wongareonwanakij S. and Hongthongdaeng B., Quantitative determination of 1-deoxynojirimycin in mulberry leaves using liquid chromatography-tandem mass spectrometry, J. Pharm. Biomed. Anal. 44, 853-858 (2007).

Obrosova I.G., Increased sorbitol pathway activity generates oxidative stress in tissue sites for diabetic complications, Antioxid. Redox. Signal. 7, 1543-1552 (2005).

Palsamy P. and Subramanian S., Modulatory effect of resveratrol on attenuating the key enzymes activities of carbohydrate metabolism in streptozotocin-nicotinamideinduced diabetic rats, Chemico-Biological. Interactions. 179, 356-362 (2009). 
Reeves P.G., Nielsen F.H. and Fahey G.C., AIN-93 purified diets for laboratory rodents: final report of the American Institute of Nutrition adHoc writing committee on the reformulation of the AIN-76A rodent diet, J. Nutr. 123, 1939-1951 (1993).

Rodríguez-Sánchez S., Hernánde -Hernández O.H., Raiz-Matute A.I. and Sanz M.L., A derivatization procedure for the simultaneous analysis of iminosugars and other low molecular weight carbohydrates by GC-MS in mulberry (Morus sp.), Food Chem. 126, 353-359 (2011).

Rodríguez-Sánchez S., Raiz-Aceituno L., Sanz M.L. and Soria A.C., New methodologies for the extraction and fractionation of bioactive carbohydrates from mulberry (Morus alba) leaves, J. Agric. Food Chem. 61 (19), 4539-4545 (2013).

Srivastava S.K., Ramana K.V. and Bhatnagar A., Role of aldose reductase and oxidative damage in diabetes and the consequent potential for therapeutic options, Endocr. Rev. 26(3), 380-392 (2005).

Sun F., Shen L. and Ma Z., Screening for ligands of human aromatase from mulberry (Mori alba L.) leaf by using high-performance liquid chromatography/tandem mass spectrometry, Food Chem. 126, 1337-1343 (2011).

Suzen S., Evcimen N.D., Varol P. and Sarikaya M., Preliminary evaluation of rat kidney aldose reductase activity of 2-phenylindole derivatives: affiliation to antioxidant activity, Med. Chem. Res. 16, 112-118 (2007).

Tapp R.J., Shaw J.E. and Zimmet P.Z., Albuminuria is evident in the early stages of diabetes onset: results from the australian diabetes, obesity, and lifestyle study (AusDiab), Am. J. Kidney Dis. 44(5), 792-798(2004).

Tietz N.W., Fundamentals of clinical chemistry, $2^{\text {nd }}$ ed. Philadelphia, NW Tietz, editor (1994). 
Uchiyama M. and Mihara M., Determination of malondialdehyde precursor in tissue by thiobarbituric acid method, Anal. Biochem. 86, 271-278(1978).

Ventura-Sobrevilla J., Boone-Villa V.D., Aguilar C.N., Román-Ramos R., VegaÁvila E., Campos-Sepúlveda E. and Alarcón-Aguilar F., Effect of varying dose and administration of streptozotocin on blood sugar in male CD1 mice, Proc. West. Pharmacol. Soc. 54, 5-9 (2011).

Volpato G.T., Calderon I.M.P., Sinzato S., Campos K.E., Rudge M.V.C. and Damasceno D.C., Effect of morus nigra aqueous extract treatment on the maternal-fetal outcome, oxidative stress status and lipid profile of streptozotocin-induced diabetic rats, J. Ethnopharmacol. 138, 691- 696 (2011).

Wayne P.A., National committee for clinical laboratory standards. procedure for the collection of diagnostic blood specimens by venipuncture, approved standards. $4^{\text {th }}$ ed. NCCLS document H3-A4 (1998).

Witko V., Nguyen A.T. and Descamps-Latscha B., Microtiter plate assay for phagocyte-derived taurine-chloramines, J. Clin. Lab. Anal. 6, 47-53 (1992).

Yassin M. and Mwafy N., Protective potential of glimepiride and nerium oleander extract on lipid profile, body growth rate, and renal function in streptozotocin induced diabetic rats, Turk. J. Biol. 31, 95-102 (2007).

Yildirim Ö., Cobalt and ascorbic acid treatment: effects on tissue nitric oxide levels in streptozotocin diabetic rat, Commun. Fac. Sci. Univ. Ank. Series C. 22(1), 1-14 (2010). 


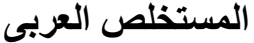

كفاعة المستخلصات المائية للتوت المصرى فى السيطرة على مضاعفات إعتلال الكلى فى الجرذان المصابة

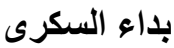

هبه بركات ـ نورا محم الثيخ - هدى اسماعيل مجاهد

قسم الكيمياء الحيوية و التغذية

كلية البنات للاداب و العلوم و التربية ــامعة عين شمس - القاهرة ـمصر

الهدف من البحث كان تعيين افضل مذيب لاستخلاص قلويد DNJ من أوراق وثمار نبات التوت

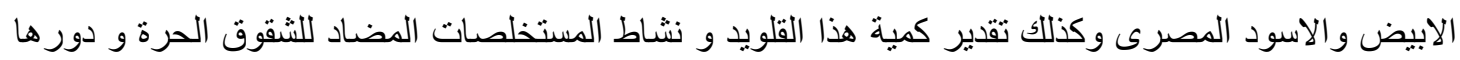

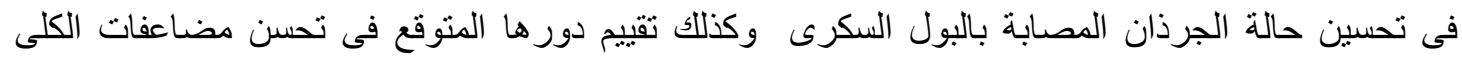

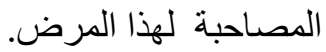

تم تقسيم 72 من ذكور الجرذان البالغين الاصحاء الى 6 مجموعات منساوية العدد المجموعة الاولى ضابطة إبهاء

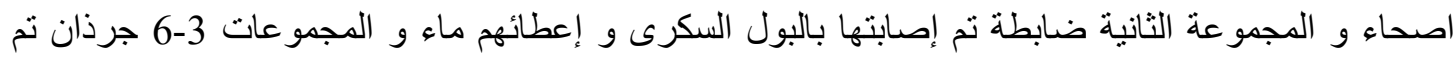

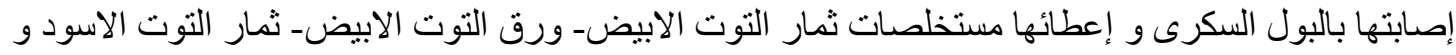

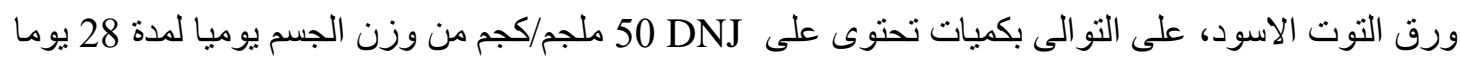

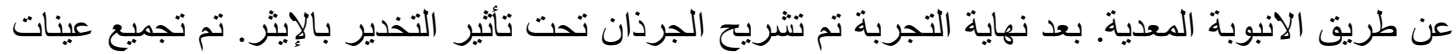

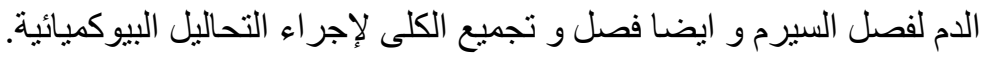

اظهرت نتيجة تحليل HPLC ان المستخلصات المائية احتوت على اكبر كمية من مادة لمئ DNJ مقارنة بالميثانول

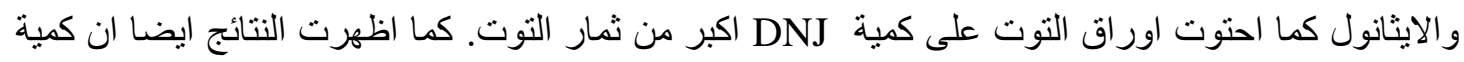
فى التوت الاسود اكبر من التوت الابيض ـ كما اوضحت نتائح التحاليل البيوكيميائية ان إعطاء

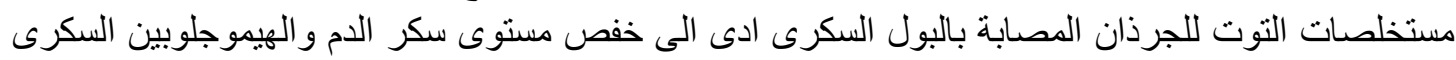

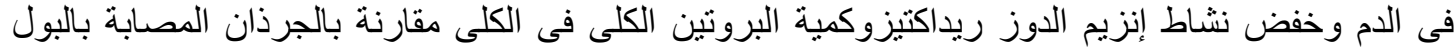

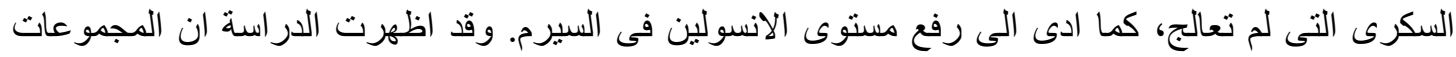

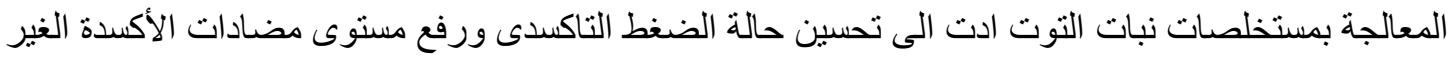

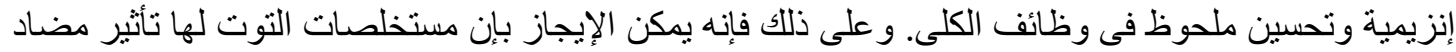

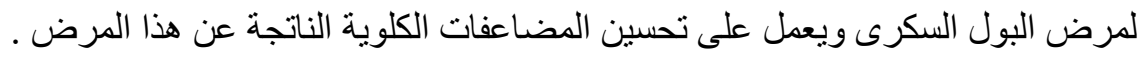

